On Names in South Asia: Iteration, (Im)propriety and Dissimulation

\title{
Naming the Deity, Naming the City: Rama and Ayodhya
}

\section{Deepak Mehta}

\section{(2) OpenEdition}

\section{Journals}

Electronic version

URL: http://journals.openedition.org/samaj/4053

DOI: $10.4000 /$ samaj.4053

ISSN: 1960-6060

\section{Publisher}

Association pour la recherche sur l'Asie du Sud (ARAS)

\section{Electronic reference}

Deepak Mehta, "Naming the Deity, Naming the City: Rama and Ayodhya », South Asia Multidisciplinary Academic Journal [Online], 12 | 2015, Online since 21 October 2015, connection on 08 January 2020. URL : http://journals.openedition.org/samaj/4053 ; DOI : 10.4000/samaj.4053

This text was automatically generated on 8 January 2020 .

\section{(c) (i) $\odot$}

This work is licensed under a Creative Commons Attribution-NonCommercial-NoDerivatives 4.0 International License. 


\title{
Naming the Deity, Naming the City: Rama and Ayodhya
}

\author{
Deepak Mehta
}

\section{AUTHOR'S NOTE}

Many thanks to the anonymous referees for their meticulous comments and important suggestions. I would also like to thank Pratiksha Baxi and Yasmeen Arif for criticism and for inviting me to present this work in the respective research colloquia run by them. The generosity of Jacob Copeman and Veena Das is more than matched by their acute insights and observations regarding this paper.

'When you were young you were called Ramabhadra. As you grew older and looked beautiful, the people named you Ramachandra; when you commenced to speak, they called you Vedha-Brahma; Raghunatha on your ascension to

the throne, and Janaki-pati when you were married to Janaki. I bow to you, 0 king of the gods,

Mahatma, and the life of Janaki'

Ayodhya Mahatmya 1875: 142-43

'The mystical analysis of the word Ayodhya has its roots in the doctrine of the eternity of sound,

combining in itself the iconography of the terrestrial city and the sound of divine reality... The linguistic etymology that follows this mystical one explains the word "a-yodhya" as meaning unconquerable'

Bakker, Vol. II 1986: 23 
1 The town of Ayodhya, situated in the district of Faizabad in the state of Uttar Pradesh in north India, is a place of pilgrimage for devotees of the Hindu god Rama. Ayodhya, they hold, is his janmasthan (birthplace) that is marked by a temple. ${ }^{1}$ Until December 1992 the birthplace was also the site of a mosque, known since the 1940 s as the Babri Masjid. ${ }^{2}$ From at least the middle of the $19^{\text {th }}$ century Ayodhya has witnessed bitter violence between Hindus and Muslims regarding the exact status of this spot. Hindu believers argue that the Babri Masjid, constructed in 1528 by a general in the army of the Mughal emperor Babur, took the place of the razed temple of the janmasthan. In law we find a long history of litigation-since 1885 civil courts at various levels of the judicial hierarchy (Sessions Courts, District Courts, High Courts and the Supreme Court of India) have debated the status of the temple-mosque complex. This litigation is ongoing and there is nothing to suggest a resolution. ${ }^{3}$ The judicial record names this complex as the Ayodhya dispute. Beginning in the 1980s, a number of Hindu organizations, collectively called the Sangh Parivar, advocated the destruction of the mosque and its replacement by a grand temple dedicated to Rama. Following prolonged political and religious mobilization, Hindus congregated at its site demolished the mosque on 6 December 1992. The Liberhan Commission of Enquiry estimates that about 150,000 people had gathered around the temple-mosque complex on that day and that 150 'karsevaks' (religious workers) actually participated in its destruction. ${ }^{4}$

2 Given that the Ayodhya dispute is extensively covered in civil and criminal law, how might we construct claims and counter claims-to property, modes of worship, rules of evidence and the demands of secularism? ${ }^{5}$ In this paper I follow a slightly different line of enquiry by asking myself how claims to the past are reckoned and admitted in courts of law. These declarations of rights, almost without fail, denote a complex that exceeds what is specifically being argued. From the point of view of Hindu worshippers, these claims to the past are detailed in the proper noun, which designates an ensemble of virtues tied to specific architectural sites in Ayodhya. In this way we may draw the relation between the Rama deity and the city of Ayodhya. The resonance of these two names in law provides the most commodious frame within which the dispute may be understood. From the point of view of Muslim claims after 1992, the Babri Mosque has lost its character as a mosque, but leaves traces of its disappearance in law. What has disappeared can be identified and named, but its 'en-tonguing' in law is a betrayal of being, since the name Babri Mosque does not ensure the presence of its materiality, much less Muslim forms of worship. $^{6}$

3 I rely on two types of texts to make my case. Separated in time by 130 years, the importance of these records is that they index a community of names that continue to carry ethical weight in the present. The two texts-the Ayodhya Mahatmya (Testament to Ayodhya; henceforth AM) of 1875 and the Allahabad High Court Judgment of 2010 (2010 ADJ I, II, III, [Special F.B.]) provide a glimpse into possible worlds, marked by the appearance and power of Hindu deities and the disappearance of the Babri Mosque. ${ }^{7}$ In reading these two texts together I show how the High Court decision is aligned to the Ayodhya Mahatmya. The Mahatmya passes on a textual object to the High Court-the many names of Rama. In this passing there is more than a simple confirmation of the High Court decision. This transit, marked by a temporal continuity, rests on the repertoire of the names of Rama tied to the spaces of the town. The result is a conventional orienting framework that almost stages the High Court decision with the AM acting as a thesaurus for the name. In this text the names of Rama occur as a constellation of ritual practices, 
while in the High Court, these practices unfold or, are more appropriately, organized into a stretch of legal discourse, hived off from empirical evidence. In effect, such practices are 'entextualized' in the way that Barber (2007: 107-109) uses the term.

The Allahabad High Court verdict of 2010 attempted to provide a solution to the 125-yearold Ayodhya dispute by a threefold division of the property of the complex. The majority decision gave the litigants-two groups of Hindus and one of Muslims, an equal share. The AM of 1875 finds explicit mention in the judgments. A year later the Supreme Court overturned this verdict. As it stands now, the four basic suits that make up the dispute in civil jurisdiction are being heard and argued in the Allahabad High Court sitting at Lucknow. In its destruction, the mosque leaves traces of its fading in law-it is almost as if the name, Babri Mosque, is a necessary condition for inscribing disappearance. Although after 1992 the Babri Mosque is not available as an architectural structure, its circulation in the High Court judgment is presupposed as the background of the judicial decision. This decision, in turn, rests on what remains in place of the mosque. In part what remains are ruins, but also in part, a re-imagination of Rama and the city. I begin with this reimagination.

5 The pair, Rama-Ayodhya has magical powers. The union of these two terms reveals the link of architectural place to mythic time, a bond that is ostensibly a non-negotiable example of our politico-religious present. Furthermore, the pair is shrouded in an aura signalling that this is the place where the Rama temple should have been, or will be, constructed. The aura, given the troubling presence of the absent mosque, indicates the inability to express fully the meaning of the pair according to the rules of a predictable truth game. This is because the couple marks the place where historical knowledge sees its competence impugned. In its place Rama-Ayodhya signposts a view of time that is both continuous and broken. In one type of text, Rama and Ayodhya are employed as if their designation were stable and all the units-symbols, icons and forms of prayer-depending on their relationship were already collected into an integrated and timeless complex. But secondly, the pair's open future emerges from the ongoing movement of the past as it comes to inhabit contemporary legal accounts. This emergence is unstable: Rama and Ayodhya signal an open, chaotic union where forms of prayer and revealed symbols jostle for space in the legitimacy of the nation-state. This paper unpacks this temporality by centring on the discursive content of the two names-Rama and Ayodhya. In so doing my intention is to show how Ayodhya is materialized through the many names of Rama, and how the deity Rama, in turn, is invigorated in the geography of this temple town.

For the above reasons, rather than consider Rama and Ayodhya as 'rigid designators,' I will discuss the relationship between them in terms of a family resemblance. ${ }^{8}$ By this I mean that the significance of both Rama and Ayodhya is maintained by dense networks of water bodies and buildings; together the two names alert us to a cluster of virtues, which endure and subsist, as much as they develop in response to change; together, the two are a past, but a past that inhabits the present. As a complex of enduring virtues the pair fixes space to time; as a complex of mobile centres, the pair functions like a parasite, leaching off secular law and seeming to provide its raison d'etre. That is to say, the only way in which the Allahabad High Court decision admits the validity of Hindu claims is by acknowledging the tractability of mythic time in its proceedings. In this way, Rama and Ayodhya provide a counter to historic time and rules of evidence based on empirical detail, thereby exposing secular law's insufficiency. 
7 At the heart of this paper is an attempt to understand how these two names intersect. Rather than showing their referential and predicative qualities, I will argue that the relationship between these names allows us to think of the present as ceaseless. But this perpetual present is also marked and disrupted by the absent Babri mosque. The value of this mark is that, at least in the legal record, it haunts the link of Rama to Ayodhya. It could be argued that this haunting becomes possible since the name Rama is empty-it occurs in fiction and has no semantic function other than its place in a story. I do not consider the name Rama to be empty. Nor do I ask whether Rama really existed since that question is unintelligible. In terms of the texts that I am considering, the story of Rama in Ayodhya is not merely a commemoration but a kind of unlimited chart, where all duration, corporeal and ethereal, can be located in relation to the fixed and determinate guidelines of the Hindu calendar. As I see it the semantic function of Rama, in the context of Ayodhya, is to designate others, specifically, the town and to ground this designation in the calendar. In so doing, the question that is asked by both the Ayodhya Mahatmya and law is: what makes life possible? As answer, one may say that the virtues by which life is made liveable are drawn out in the Mahatmya and it is these virtues that are exalted in law as action in the present. But this answer assumes an unbroken temporal continuity between the Mahatmya of 1875 and the High Court judgment of 2010. I suggest that this stability is disrupted by a third name that cannot be invoked in this complex of virtues. This third name is of course the Babri Masjid.

8 This paper is divided into two parts. In the first, taking the Ayodhya Mahatmya, I will detail the ways in which Rama and Ayodhya are predicates of named terrestrial spaces and water bodies. Together, the force of these predicates is activated by religious pilgrimages and oblations organized around the Hindu festival calendar. In this way the material city and the deity are tied to eternal, ceaseless time. In the second part I will argue that this temporality is negotiated and contested in secular law, specifically in pronouncements and testimony that consider how the Rama deity establishes dominion over the janmasthan (the place where Rama was born) and the janmabhumi (the town of Ayodhya). But a third name-the absent Babri Mosque-in haunting judicial accounts of this dominion, functions like a spectre, inflecting judicial pronouncements with the force of historical facticity.

Within the history and mythology of Ayodhya, the name may, in the sense outlined above, point us to an eternal present as well as a revenant. Derrida (1994) uses the metaphor of haunting to witness unsettled and troubling histories-a plea for justice on behalf of those who are not there. Half suppressed memories appear and disappear among us in the manner of a revenant. Haunting for Derrida is a crossing between presence and absence-what he calls the 'spectrality effect' (1994: 48), an effect that houses ghosts. The Babri mosque, too, may be understood as a revenant, but in a way that is more literal and agentive than Derrida's revenant. The mosque here is not merely a rhetorical figure that undoes the binary between presence and absence. Its demolition puts into crisis, or at any rate introduces, instability in law. In law, the mosque is constituted and reconstituted in Ayodhya, but as a figure that is central in its absence from its geography. Debates around this absence force secular bureaucrats and judges to engage with popular (and populist) Hindu religiosity, pointing, in the process to the name Babri Masjid as an unquiet absence. The ghostly claims of this name carry ethical weight in the resolution of the Ayodhya dispute, indicating a sense of rights and obligations, sometimes contested, at other times glossed over between those who argue for the Rama 
temple and those who plead for the presence of the demolished mosque. Sometimes, quite literally, we hear of laments for a lost burial ground, as if the memory of the dead has also been killed. But if the plight of the mosque evokes a vision of ethical order projected onto the court, its condition as a ghost, as haunting, is a condition of unpredictability and paradox.

\section{Ayodhya Mahatmya} Parvati. Siva proclaims the Ayodhya Mahatmya and Parvati acts as an interlocutor, wanting to know the significance of particular places in the city. ${ }^{9}$ The text begins by providing a broad outline of Ayodhya, detailing its mythic origins and establishing its dimensions. ${ }^{10}$ The 1875 AM says that it was built on Rama's sudarshanchakra (chariot), while other recensions say that Visvakarma built the city. In the text Ayodhya resembles the eternal city of the gods but what is specific is that the celestial city is linked to forts, palaces, city halls and lakes that are found in the actual town. The AM provides an outline of the holy kshetra (field) around the town. The traditional dimensions of the town are 12 yojanas (1 yojana $=7 \mathrm{~km})$ in length and 3 yojanas in width. The rivers Saryu and Tamasa form the northern and southern borders of the holy places in the city. Most pilgrimages described lie within these borders, although this paraphrase describes some holy places to the south of the Tamasa as well. The average distance between the two rivers is about 20 kilometres. The city is said to have the form of a fish of which the head lies in a ford of the Saryu river, called Gopratara and the tail at an unspecified part in the east.

As we know it now, Ayodhya is located on a curve of the Saryu River, which girdles the town on three sides. The eastern and western boundaries are made up of marshes, with the latter spreading to neighbouring Faizabad. The middle of the town known as Kot Ramchandar or Ramkot, is dotted with innumerable temples and maths (monasteries). The southwestern side of Ramkot, named Kubertila, is strewn with bricks and stones, most of them from the demolished Babri mosque. The 1875 edition describes Ramkot as a fort ringed by gates and protected by Hanuman, Sugriva and Angad, Nala and Nila, and Sokhain. Just beyond the fort, at its eastern, western and northern boundaries, splendorous palaces are described, made up of gem encrusted stones and diamonds.

In the centre of Kubertila is the janmasthan, which is also the site of the demolished Babri mosque. The most conspicuous fact relating to the pilgrimage around the janmasthan is that a description of this principal holy place is found in all the recensions of the AM, and yet the pilgrimage is not mentioned in any of the classical sources. 'Such a silence is all the more surprising in view of the fact that archaeological evidence indicates the existence of a temple at this tirtha [pilgrimage] in the eleventh century' (Bakker, Vol. II: 143). The AM connects the janmasthan with an elaborate description of Ramnavmi (celebrated as the birthday of Rama) and provides the spatial dimensions within which the birth occurred. This area stretches more than 500 dhanus (910 metres) westwards of the dwelling of a sage called Lomasa, 1008 dhanus (1835 metres) eastwards of a monastery occupied by the Ramanandi sect, called Vighnesvara and 100 dhanus (182 metres) from Buddhist ruins called Unmatta, in an unspecified direction. In the middle of this area the royal palace called janmasthan is situated. A monastery called Ramgulela is believed to represent Lomasa. Janaki's kitchen, the text says, is northwest of the janmasthan, and 40 yards to the north of janmasthan is the house of Kaikeyi (the mother of Rama's brother, 
Bharata). 60 yards to the south of this house is the dwelling of Sumitra, mother of Rama's younger brothers, Satrughana and Lakshmana. Southeast of the janmasthan is the sitakup, also known as the Jnanakup. The sages, Brihaspati, Vasishta and Vamadeva drink its waters.

After the demolition of the mosque in Kubertila, a makeshift temple, apparently marking the exact place of the birth of Rama, was erected in the central dome. The temple is enclosed by railings and is guarded by a number of security personnel. No Muslims are allowed to enter the precincts and Hindus may come only as far as the fence in front of the entrance gate. The temple itself is located on a small altar, near which groups of Hindus engage in continuous prayer and kirtana (hymn). During my visit to Ayodhya in 2008, a pamphlet (in English) distributed among pilgrims read:

Shri Ramjanmabhumi of Ayodhya is a very sacred place. Anticipating Hindu-Muslim friction, the Govt. has declared it a disputed place and has taken possession over it. Regular case is being conducted in the civil and criminal court. Since December 27, 1949 day and night Akhand Kirtan [unlimited chanting or hymn] is being performed with a determination that it will continue so long as Ramjanmabhumi is not freed. It is the sacred duty of the entire Hindu Community to finance this holy cause donations (sic) and thus earn immense PUNYA [virtue and grace].

The deities can be seen through iron railings and offerings can be made through their bars. On special occasions groups of Hindus, eleven to a unit, are allowed to proceed beyond the railing to worship Rama and his brothers' deities.

The ghats (bathing places), the most important of which is known as Svargadvara (lit. gate to paradise), are situated along the Saryu and lie about 700 meters to the north of Ramkot. Gopratara, about 8 kilometres to the west of Ramkot, is the site of a second major bathing place. The 1875 AM says that Svargadvara, known also as Negeshvara and Muktidvara (gate of deliverance) is at 318 yards to the east of the thousand-streamed Lakshmana kund (pond or lake). 'All men, Hindus and Muslims, who die here go to the place of Vishnu,' and that 'Ramachandra in the form of Bharata, Satrughan, Lakshmana and his own, greet them there.' Svargadvara is made up of seven ghats: Chandrahari, Guptahari, Chakrahari, Vishnuhari, Dharmahari, Bilvahari and Punyahari. These baths are said to extend over a distance of 636 dhanus (1157 metres) to the east of Sahasradhara. Effectively, this includes the entire northern and north-eastern side of Ayodhya along the riverbed as far as another bathing place known as the Janakitirtha. A ruined mosque, dating to the time of Aurangzeb called Treta-ke-Thakur, is located 250 metres east of Chandrahari. Various temples lie along these ghats-the Saryumandir and the Nagesvaranathmandir are the important ones. The more recent ones are called Caturbhuji ka Mandir and Vidhiji ka Mandir, both occupied by the Ramanandi sect. Associated with these bathing places are water bodies, mainly ponds or lakes. This AM names more than 50 water bodies, most of which are associated with pilgrimages during specific months of the lunar calendar.

For purposes of brevity we may establish the following link between water bodies, pilgrimages and terrestrial palaces/residential buildings.

\begin{tabular}{|l|l|}
\hline KUNDS & PILGRIMAGE \\
\hline Madant Dhavan (bathing area) & $9^{\text {th }}$ day of the dark half of Chait (March-April) \\
\hline
\end{tabular}




\begin{tabular}{|c|c|}
\hline Hanumat & Every Tuesday \\
\hline Sugriva (south of Hanumat) & On Ramnavmi (light half of Chait) \\
\hline Vibhishana (south of sugriva) & On Ramnavmi (light half of Chait) \\
\hline Agnikund (s.w. of Suvarnakhana) & 1st day of dark half of Agrahayana (Nov-Dec) \\
\hline Sitakund (middle of Asoka Vatika) & $4^{\text {th }}$ day of dark half of Agrahayana (Nov-Dec) \\
\hline Kharjurakund (s. of Vidyakund) & Every Sunday \\
\hline Kausalyakund (w. of dasrathkund) & Last day of Bhadra (August-September) \\
\hline Sumitrakund (w. of Kausalyakund) & $15^{\text {th }}$ day of Bhadra (August-September) \\
\hline Kaikeyikund (s. of Sumitrakund) & $15^{\text {th }}$ day of Bhadra (August-September) \\
\hline Urvashikund (e. of Yoginikund) & $3^{\text {rd }}$ day of the light half of Bhadra (August-September) \\
\hline Vrihaspatikund (e. of Urvashikund) & $5^{\text {th }}$ day of the light half of Bhadra (August-September) \\
\hline Rukminikund (e. of Vrihaspatikund) & $9^{\text {th }}$ day of the dark half of Kartika (Oct-Nov) \\
\hline Sagarakund (n.e. of Vasisthakund) & Last day of Kartika (Oct-Nov) \\
\hline Brahmakund (n.e. of Sagarakund) & $4^{\text {th }}$ day of the light half of Kartika (Oct-Nov) \\
\hline Rinamochan $^{11}$ (n.e. of Brahmakund) & Dark half of Magha (Jan-Feb) \\
\hline
\end{tabular}

Just as water bodies are associated with specific pilgrimages, so also terrestrial places are linked to pilgrimages. The following is a small list.

\begin{tabular}{|l|l|}
\hline PLACES & PILGRIMAGES \\
\hline Svargadvara & Full moon of Jyaistha (May-June) \\
\hline Janmasthan & Fast on Ramnavmi, bright half of Chait \\
\hline Vidya pith (w. of Vidya kund) & $8^{\text {th }}$ day of every month \\
\hline Vishnuhari shrine (w. of Dhanyaksha) & $10^{\text {th }}$ day of light half of Kartika (Oct-Nov) \\
\hline Sitaladevi temple (n. of Mantresvara) & Every Monday \\
\hline Bandidevi temple (n. of Sitaladevi) & Every Tuesday \\
\hline House of Rishyasringa Rishi & Light half of Chait (March-April) \\
\hline Bhairav temple (s. of Ramkund) & Dark half of Agrahayana (Nov-Dec) \\
\hline
\end{tabular}




\begin{tabular}{|l|l|}
\hline Nagari temple (near Lakshmi temple) & Light half of Bhadra (Aug-Sept) \\
\hline Sapneshvaradevi temple & $8^{\text {th }} / 14^{\text {th }}$ of every month \\
\hline Ramrekha (s.e. of Manorama) & Light half of Kartika (Oct-Nov) \\
\hline
\end{tabular}
the city. Each pilgrimage, each oblation offered establishes a present marked by the infinite repetition of virtue. In the process, this present adjudicates the practice of affirming the birthplace and the land of birth of the Rama deity. The importance of these virtues is that they invigorate and make whole the worshipper in the city and it is in this way that the calendar itself becomes an ethical doctrine. Against the postulate of a beginning and an end, the calendar establishes a present. When the birthplace and the land of birth enter adjudication, we find explicit references to the Rama deity and the birthplace as jural beings. In the process, the Babri Mosque circulates in articles of law and loses its specificity as an architectural entity. It becomes a revenant. For this reason, if law accounts for the finitude of the Ayodhya dispute, then the placing of the Rama deity at the heart of its decisions is not without its problems. It is to this problematic placing that I now turn. 


\section{The revenant in the High Court}

21 In tracing the revenant and its disruptive presence I consider two modes of judicial accounting. In the first part I read the accounts of witnesses called to testify in the High Court, specifically as they describe the demolished Babri mosque and the family of terms within which it is enveloped..$^{13}$ The second section details how the three judges, in their separate findings, made a case for the jural deity and named this mosque. In testimony we get a kind of messianic time that is activated through pilgrimages and ritual observances, but a time that almost always looks sideways at the absent mosque, while the decisions of the three justices show how the demolition is worked upon and made habitable in law. In the process, rather than indicating the demands of this or that litigant, these decisions act like a speech prosthetic, by which inanimate objects (such as the deity and the mosque) become voluble. While the deity is enmeshed within an eternal present, the demolished mosque dislocates. The decisions orient themselves to this doubling by pointing to a vertiginous simultaneity of time. The mosque haunts this eternal present. Gordon (1997) thinks of haunting as signifying a social figure, which is then mined for its poetic potential. Rather than consider the mosque as a unit of signification I follow its career not simply for the poetic potential that it allows, but because its demolition and subsequent appearance as a ghostly figure puts into crisis the future of the Rama temple itself. ${ }^{14}$

Before I present the testimonies I will outline how they are framed within the 'gist of the findings' of the three judges.

Justice SU Khan: The 'disputed structure' was constructed as a mosque by and under orders of the Mughal emperor Babur and no temple was demolished in its construction. But the mosque was constructed over the 'ruins of temples,' which were lying in 'utter ruins' for a very long time (2010 ADJ I: 115).

24 Justice SC Agarwal: It is declared that the area covered by the 'central dome of the threedomed structure, i.e., the disputed structure being the deity of Bhagwan Ram Janamsthan and place of birth of Lord Rama as per faith and belief of Hindus, shall not be obstructed or interfered in any manner by the defendants' (2010 ADJ III: 2871).

25 Justice Dharamveer Sharma: The 'disputed structure is the birthplace of Lord Rama. The place of birth is a juristic person and a deity. The disputed building was constructed by Babur, the year is not certain, but it was built against the tenets of Islam [...]. The disputed structure was built on the site of an old structure after demolition of the same. Thus, the structure could not have the character of a mosque.' (2010 ADJ III: 3453)

What is clear is that the 'disputed structure' or three-domed structure (never the Babri mosque) was associated with ruins, with obstruction and interference and with demolition. We will see later how these terms, in alliance with proper nouns, come to circulate in the judicial account.

27 Testimony 1: Mahant Ram Vilas Das Vedanti, (in his affidavit of 2005 he says he is 51 years old. He was cross-examined by Tarunjeet Verma representing the Nirmohi Akhara, and by Zafaryab Jilani representing the Sunni Waqf Board). Ram Vilas, at the time of his deposition claimed to be the priest of a temple and had been living in Ayodhya since 1968. He holds a doctorate in grammar from the Varanasi Sanskrit College. 
Prior to the demolition of the disputed structure at the Sriram Janambhumi premises, the main gate for entry was in the east, which was called the Hanumatdwar [...]. On entry to the disputed structure a platform towards the south was called Ramchabutra, where the idols of Lord Rama, Laxman, Sita, etc. were present and were worshipped regularly by Hindu devotees. Below the Ramchabutra was the 'cave temple.' [What follows is an elaborate architectural description of the birthplace, ringed as it is, by a series of proper names of Hindu deities and places mentioned in the Ayodhya Mahatmya of 1875].

Testimony 2: Raja Ram Pandey, 87 years old (affidavit of 2003), cross-examined by Zafaryab Jilani representing the Sunni Waqf Board.

Raja Ram Pandey was a resident of Kaushalya Ghat in Village Ramkot, the site of the demolished mosque. He had been living in Ayodhya since 1930.

In March 1934 a Hindu-Muslim riot occurred when many Muslims were killed and a large number of graveyards were damaged, but no part of the Sriram Janmabhumi temple or its dome was damaged. The outer wall was damaged slightly. The Muslims were terror-stricken and they stopped going towards the temple. I was 1920 at that time.

What follows in this testimony is the same elaborate description of the architecture of the birthplace, of the deity and the form of worship.

Testimony 3: Narendra Bahadur Singh, 72 years (affidavit of 2004, cross-examined by the same lawyer as in Testimony 2).

I gained maturity at the age of about 11 years [...]. The structure collapsed on 6 December 1992 and thereafter my visits to the temple were reduced.

As with the other accounts, this one is rich in details on the geography of the birthplace, the place of deities and the various pilgrimages that occur around the year.

If Hindu accounts were meticulous in their evocation of the birthplace, Muslim testimonies focused on the status of the mosque.

Testimony 4: Maulana Atiq Ahmad, 47 years (affidavit of May 2010. Cross-examined by the advocates of the Nirmohi Akhara and by the Next Friends of the Deity).

Nowhere in Islam does the style of mosque construction find specific mention. The name 'masjid' is given to a piece of land that is gifted for offering Namaz. Even if this building has no domes or minarets, it will be called a masjid. Even if there is a graveyard in the vicinity of the mosque, that does not change its character. You killed our people, you destroyed our graves. But the mosque remains. A mosque once constructed will always be a mosque [...]. If the followers of other religions start practicing their religious faith in a mosque, then also the status of the mosque does not change.

Other Muslim testifiers echo much the same sentiments.

In which way does the decision of individual judges intersect with such testimony? In considering the expectations of the litigants, the High Court judges actualize legal operations by consolidating existing norms, projecting their effects into the future and attempting to produce expectations based on re-installed or altered norms.

Let me briefly indicate the direction of how I think the name is being used in the pair Rama-Ayodhya. In the judicial decision, the name delivers the expectations of the litigants. In eliding the historical facticity of the mosque, the judicial decision also conveys that what is there differs from what is or was present before 6 December 1992 . The names of Rama and Ayodhya are present in and of themselves. What becomes present after the demolition contracts into what is accessible as worship, as deity and birthplace. 
But the mosque returns and splits this access into what was present before 1992 and what is really there. The disputed structure complex, in its alliance with the destroyed cemetery, becomes a metonym for Rama and Ayodhya, ensuring that this place-name will forever be incomplete. This is because the Babri Mosque haunts the deity and its birthplace in appropriately spectral ways, an absence that sits side-by-side with an assumed presence, a stubborn response to the sacredness of Rama and Ayodhya.

For this reason, too, in Ayodhya Hindu worship is not without its doubts. With reference to the 'Rama temple' there is a kind of precautionary formula used in prayer. When I visited Ayodhya in 2008 I was advised to use expressions like, 'whether you want to be called Rama or Lakshmana, or Gopal, hear my voice,' and 'if this is the name by which you would like to be called.' Underlying this call to the name are the following sorts of questions. Do you need to know the name of the deity you're praying to? If you get the name of the deity wrong, what happens to your prayer and your oblations? Who gets to decide whether the name works? (You, or the deity, or neither?) The name and birthplace of the deity are, as I have tried to show, not only a declarative (by which you move from the name to the city and vice-versa), whose invocation in law establishes an institutional fact, but also a mode of censorship by a specific community of Hindu devotees. The avowal of the name of the deity here must rest on a disavowal of the Babri Masjid. In other words, these questions sense the frisson of a spectral presence circulating uncertainly in articles of law but without material presence. It is not inconceivable that the Rama temple, if it is constructed on an officially controlled landscape, will not quite shake the presence of ghosts from disturbed graves and a demolished mosque.

The Deity and the Janmasthan: The names, Rama and Ayodhya and the Babri mosque, as they occur in the 2010 judgment, have a variable and flexible character. This is understandable since they are linked to a cluster of other names, made up of single or multiple rights and virtues. We have seen that these rights and virtues that make up Rama and Ayodhya come in thick bundles and in large clusters. ${ }^{15}$ In the case of the Babri mosque the cluster of other names within which it is located is hollowed out. Instead there is something like an ontological vacancy built into this name. But before I develop this argument further let me briefly delimit the relationship of Rama to Ayodhya. Put more elaborately, how is the juristic personality of the deity framed within the backdrop of the demolition of the Mosque, and how do we find a place for gods in the adjudication around the dispute? ${ }^{16}$

An obvious dimension of the name Rama is its relationship to property as Ayodhya. If the proper name denotes a person, in a common-sense way one assumes that person and property (being a thing) are mutually exclusive. The 2010 judgment, we will see below, qualifies this distinction, by showing that the legal rights and duties that make someone count as person and something count as property are shifting and variable. The name Rama bears the features of property, particularly janmabhumi and janmasthan, as much as it is exalted as a virtuous god-king. This doubling-of property and virtue-is found in the Allahabad High Court decision, but also in the lease deed executed between the Uttar Pradesh state government and the Shri Ram Janmabhumi Trust in 1992. Earlier in 1989, the Uttar Pradesh state government had acquired the land around the Babri Mosque and the plan was to build a grand temple dedicated to Rama. The Trust was established in 1989 to oversee the construction of a grand temple.

The object of the Trust was to establish a religious theme park over state acquired land, approximately 56 acres that surrounded the mosque and various Hindu temples. The 
lease mentions that the object of the park was to, "create experience of the cultural aspects emerging from the great epic Ramayana [...]. The park should be integrated with the overall development of that Ayodhya mentioned in the great Mahatmyas.' A state appointed surveyor mapped, scheduled and delineated the red-boundary plot of land over which the park would be built. It would be called the Ramkatha Park, reflecting ostensibly the relation between the Kingdom of Rama and the present. The lease announced the precise birthplace of Rama, known as the janmasthan, and Ayodhya the janmabhumi. It would also function as the object of nationalist-religious pedagogy where inhabitants of the complex, dressed in Vedic period costume, arranged guided tours for school children. What was, thus, set in motion was a process of landscape interpretation, with the mosque as an ever-present eyesore. The lease deed, in the process, turned topography into a set enmeshed in scriptural signs that had to be read instead of being simply viewed. These signs imagined the park as a site of national regeneration and a pastoral landscape, an edited panorama, where the mosque could exist only between the visual registers of danger, Vedic authenticity and political invisibility.

41 In 1989 a suit was filed by three plaintiffs: Sri Ramalala Virajman, the Asthan Rama Janmabhumi, Ayodhya (O.O.S. No. 5 of 1989) and a Vaishnava Hindu who argued that the Rama deity, installed in the central dome of the mosque, and the place of birth were juiristic persons. It also declared that the entire premises of Sri Rama Janmabhumi at Ayodhya belonged to the plaintiff deities and asked for a perpetual injunction against the defendants (the Sunni Waqf Board, the Nirmohi Akhara, Gopal Singh Visharad and 24 others), prohibiting them from interfering with or raising objections to the construction of the new temple building at Sri Rama Janmabhumi, Ayodhya.

The Allahabad High Court attempted to resolve the above suit by arguing that both the janmasthan and Rama Lala (Child Rama), surreptitiously installed in the central dome of the Babri Mosque in 1949, were jural persons. In so doing the judges located the subject of legal rights and duties on a threshold where judicial decision was marked by a continuous emergence from a sacral past into the future. This opening into the future can be elaborated through three basic issues posed by the High Court. The first issue (Justice Khan) considered whether the deity was a perpetual minor and if so, whether this minor was subject to the Limitation Act of 1963. The second matter (Justice Agarwal) dealt with the form of divinity and belief, specifically swayambhu (self-revealed image) and pran pratistha (infusion of breath into the deity). The third concern (Justice Sharma) was the link between the deity and the image.

43 As far as the status of the deity as a perpetual minor was concerned, Justice Khan considered whether the minor was entitled to the benefit of the Limitation Act of 1963. This Act raises the following question: if a person entitled to institute a suit or make an application for the execution of a decree is reckoned a 'minor, or insane or an idiot' (ADJ I: 80), can this person institute the same suit or execute an application, after the disability has ceased? Analogically, the deity, in the position of a minor, was unable to make an application itself or institute a suit, since it suffered from the same infirmities. The Justice, however, argued that the minor status of the deity was confined only to the purpose of filing a suit-in all other instances the deity was not a perpetual minor. Furthermore, as a minor it could never be freed from this disability. This meant that if the deity were a perpetual minor, then the limitation would never come to an end. In his order, Justice Khan declared 'that the portion below the central dome where at present 
the idol is kept in a makeshift temple will be allotted to Hindus in final decree,' thus pointing to the jural status of the Rama deity (ADJ I: 80).

Just as Justice Khan recognized the legal status of the deity, Justice Agarwal argued that both the deity and its place of birth were jural persons. Citing Ram Janki Deity Vs. State of Bihar, (1999 (5) SCC: 50), the Justice held that the birthplace was self-revealed (swayambhu ), a product of infinite nature without beginning, and it was left to worshippers to simply discover its existence. Furthermore the swayambhu image did not require pratistha (consecration of breath); the act of worship gave the place the essential features of a temple. It was Justice Dharam Veer Sharma who provided the most elaborate explanation of the jural deity and birthplace.

To establish that the Babri Mosque was built after razing a Hindu temple, Justice Sharma decided to call on the assistance of 'archaeological science' (2010 ADJ III: 2927). Accordingly, the Archaeological Survey of India was directed by the Court in August 2002 to excavate the disputed site. The excavation, according to the Justice, revealed that the Ram Chabutra (platform), had 'five different structural phases in its construction' (2010 ADJ III: 2954). ${ }^{17}$ In its enlarged form it was ' 22 metres in east-west and about 14 metres in north-south orientation' (2010 ADJ III: 2954). The survey found evidence of a massive structure that could be dated from the tenth century onwards. The Justice proceeded to quote from various sources to establish that the structure was a Rama temple. Verses from the Rig Veda were put alongside expert testimony, including those drawn from the Ministry of Steel and Mines, epigraphy and histories of ancient India. In effect, the Babri Mosque had usurped the place of the Rama temple (2010 ADJ III: 2970).

Having concluded that the massive structure razed in the construction of the Babri Mosque was a Rama temple, Justice Sharma went to great lengths to prove that this structure belonged to the deity, by contending that the latter was a jural person. Furthermore, it was not only the deity that was a jural person, but the birthplace itself was a jural entity. More than the deity, the janmasthan was swayambhu (self-revealed) and did not require any form of consecration. The consequence of considering the janmasthan and the Rama deity as jural persons meant that the two could not be alienated from each other though it was only in the 'ideal sense that the idol is the owner of endowed properties' (2010 ADJ: 3409) and could have no beneficial interest in the endowment. ${ }^{18}$ The attempt nevertheless was to make a case for Hindu forms of worship and to link these forms to Ayodhya incarnated as the name of Rama. The Justice was categorical in his assertion that 'the religious right of Hindus to worship Ram Lala at the janmasthan became concretized before the Constitution came into being and the same requires to be protected,' and that no plea could be entertained to prohibit this practise (2010 ADJ III: 3439). Furthermore Ayodhya itself was marked out through parikrama (circumambulation). Circumambulation of the Rama deity was of three types-40 kose, 14 kose and 5 kose ( 1 kose is approximately two miles). In the process, the movement from janmasthan (birthplace) to janmabhumi (land of birth) was secured.

47 What place did the Mosque have in this complex of names and territory? The final section of this paper addresses the absent Mosque. Referring to one of the original suits filed by the Sunni Central Waqf Board against various Hindu defendants and the state of Uttar Pradesh, Justice Khan asked whether the demolished building was a mosque, its date of construction, the exact plot of land on which it stood, its ownership till 1949, when its owners were dispossessed, and finally whether the Hindu devotees of Rama had 'perfected right of prayers at the site by adverse possession' (2010 ADJ I: 58). ${ }^{19}$ In effect, 
the issue that concerned this Justice was one that related to property ownership. In his findings he observed that the 'disputed structure' was constructed as a mosque under direct orders from the Mughal emperor Babur and that no temple was demolished in its construction. Yet, he observed, before 1855 the Ram Chabutra and Sita's kitchen had come into existence inside the boundary wall of the mosque. ${ }^{20}$ This complex was called the Chabutra Masjid. In view of the above, both Hindu and Muslim parties and the Nirmohi Akhara were awarded joint possession of the entire premises (2010 ADJ I: 107-16). Thus, as property, in Justice Khan's estimation the Babri Mosque was linked to the disputed structure and to the Chabutra Masjid. What was absented from his order was that the mosque had also been a site of Islamic prayer. In his prelude he perhaps admitted to a sense of loss-'Here is a small piece of land (1500 square yards) where angels fear to tread. It is full of innumerable land mines. We are required to clear it [...]. We do not propose to rush in like fools lest we are blown. However, we have to take a risk [...]' (2010 ADJ I: 27).

If Justice Khan was succinct in his order, his colleague Justice Sudhir Agarwal, more than made up for his economy of words. Extending to almost 3000 pages, the judgment provides a detailed survey of various records, from beyond antiquity to the present, oral testimonies, the deposition of witnesses, a reading of public reports and the discovery of lost objects following archaeological excavations. Justice Khan's 'small piece of land,' was now fleshed out in greater detail. 'The disputed structure is divisible into three parts. (1) The main roofed structure, (2) the inner courtyard, and (3) outer courtyard [...]. On the outer courtyard there is a Chabutra which has been in possession of the Hindus' (2010 ADJ I: 128). The Babri Mosque, in this rendition was associated with the 'inner courtyard.' It was also called a 'three-arched structure,' with 'three broad but pointed arches on the façade. The liwan (sanctuary) that stood on a low plinth was composed of three square bays, roofed by three single broad and high domes' (2010 ADJ I: 128). Inscriptions in Persian and from the Quran marked the pillars of this 'three-arched structure.' And yet what was demolished was not a mosque, for the inner and outer courtyard belonged to the deity.

In answer to the claim of the Sunni Waqf Board that the inner courtyard was a mosque under the care of the waqf Board, Justice Agarwal argued that 'a deity is not damaged or comes to end due to destruction in any manner, since the spirit of Supreme Being continues to exist and it will not disappear, particularly when the deity is Swayambhu, i.e. self-created' (2010 ADJ III: 2847). The janmabhumi similarly was swayambhu. The courtyard, inner and outer, therefore had a dual character, being both deity and property. From here he argued that 'It is quite possible that the entire city may be held to be very pious and sacred on account of some occurrence of divinity or religious spirituality' (2010 ADJ III: 2848). In answer to the claim that the disputed structure was a mosque constructed in 1528 by Babur and that namaz had been offered continuously till 1949 , he said that it could not be established that the mosque was built in 1528 and that prayers had been offered in the mosque since that year. At best, the Friday prayer was offered from 1860 till 16 December 1949 and that too intermittently (2010 ADJ III: 2855). While this structure had a mutawalli (keeper of the mosque), he found the absence of a muezzin surprising. The mutawalli had not been appointed following due procedure, the possession of waqf could not be claimed by him and by extension the (Muslim) worshipper could not claim possession of waqf property. Given that there was evidence of namaz being offered at the site, the Justice held that part of the disputed structure was 
indeed a mosque, but that 'there also existed a religious place of non-Islamic character before the construction of the disputed structure' (2010 ADJ III: 2860).

If the mosque was built on usurpation could it really be a mosque? Quoting from Quranic verses Justice Dharam Veer Sharma argued that the waqif (person holding the waqf) must be the owner of property, and there is nothing on record to suggest that the emperor Babur, a Hanafi Muslim, had acquired the title of the temple. Accordingly, he could not erect a mosque against the tenets of Islam (2010 ADJ III: 2971-75). For this reason, the claim of the plaintiffs that the mosque was dedicated to Allah was decided against them. And even if the 'building' had been used by members of the Muslim community for offering prayers since the time of its construction, a non-Muslim now adversely possessed it (2010 ADJ III: 2976). Effectively, the mosque had become a temple.

\section{Conclusion}

51 In the view of the three judges of the Allahabad High Court the Babri Mosque was read in conjunction with ruins, a demolished building and property ownership. Called the Chabutra Masjid, it was set against the original Ram Chabutra and Sita's rasoi (kitchen). Justice Agarwal divided the 'Chabutra Masjid' into an inner and outer courtyard. This three-arched structure was set against the swayambhu deity and janmasthan. Justice Sharma was the most emphatic. In his view the Babri Mosque was built against the tenets of Islam itself and it could never have been a place of legitimate prayer. Common to the three accounts was the view that the Babri Masjid was a disputed structure.

The difference between the janmasthan and the mosque as it has developed in this paper rests on the two being incommensurable. While the janmasthan is marked by a singularity that encompasses the town of Ayodhya, the mosque loses all specificity and becomes instead identified with prosaic nouns-a building, three-domed, three arched. When sacrality is associated with it, the mosque is recognized by terms that evoke Hindu modes of worship. And yet, in the High Court decisions the mosque returns, not in its materiality, not even as a catastrophe, but as a legally induced position. More appropriately, the mosque is a referent without a mental image and its evocation in the High Court is set against Rama/Ayodhya, elaborated first in the Mahatmya and then taken up by two of the three judges. Split off from its mental image, the mosque in the High Court is externalized and set against the temple, which exists, perversely enough, only as a mental image, never a reference. But because the mosque is set adrift of its status as a mosque it enters into an endless circulation in law, allowing for multiple readings-as waqf property, three-domed building, Chabutra masjid and so on. In this circulation the mosque in its demolition bursts out of the past as materiality and into the present as an article in law, indicating a disruption of linear time. It seems to get in the way of the putative Rama temple and it is for this reason that the High Court tries so hard to brush it aside. 


\section{BIBLIOGRAPHY}

Ahmad, Aijaz (2000) Lineages of the Present: Ideology and Politics in Contemporary South Asia, London: Verso.

Ahmad, Sara (1996) 'Judicial; Complicity with Communal Violence in India', Northwestern Journal of International Law and Business, 17(1), pp. 320-50.

Appadurai, Arjun (1981) Worship and Conflict Under Colonial Rule: A South Indian Case, Cambridge \& New York, Cambridge University Press.

Allahabad High Court Judgment (2010) (A.D.J. 1, 2, 3 [Special F.B.]).

Bakker, Hans (1986) Ayodhya, 2 Vols., Groningen: E. Forsten.

Barber, Karin (2007) The Anthropology of Texts, Persons and Publics: Oral and Written Culture in Africa and Beyond, Cambridge \& New York: Cambridge University Press.

Benveniste, Emile (1971) Problems in General Linguistics, Coral Gables (Florida): University of Miami Press.

Davis, Richard H. (2010) 'Temples, Deities, and the Law', in Timothy Lubin, Donald R. Davis \& Jayanth K. Krishnan (eds.), Hinduism and Law: An Introduction, Cambridge \& New York: Cambridge University Press, pp. 195-206.

Derrida, Jacques (1994) Specters of Marx, New York: Routledge.

Gordon, Avery F. (1997) Ghostly Matters: Haunting and the Sociological Imagination, Minneapolis: University of Minnesota Press.

Hartung, Jan-Peter; Hawkes, Gillian; Bhattacharjee, Anuradha (2003) Ayodhya 1982-2003: The Assertion of Cultural and Religious Hegemony, University of Leicester, South Asian Academic History Papers 9.

Kilroy-Marac, Katie (2014) 'Speaking with Revenants: Haunting and the Ethnographic Enterprise', Ethnography, 15(2), pp. 255-76.

Kripke, Saul (1972) Naming and Necessity, Cambridge (Massachusetts): Blackwell Publishing.

Liberhan, Justice M.S. (2009) Liberhan Ayodhya Commission of Inquiry [Online], URL: http:// www.thehindu.com/news/report-of-the-liberhan-ayodhya-commission-of-inquiry-full-text [accessed 2 February 2014].

Lutgendorf, Philip (1997) 'Imagining Ayodhya: Utopia and its Shadow in a Hindu Landscape', International Journal of Hindu Studies, 1(1), pp. 19-54.

Mehta, Deepak (2015) 'The Ayodhya Dispute: Law's Imagination and the Functions of the Status Quo', in Roma Chatterji (ed.): Wording the World: Veena Das and Scenes of Inheritance, New York: Fordham University Press.

Mehta, Deepak (forthcoming) 'The Ayodhya Dispute: The Absent Mosque, State of Emergency and the Jural Deity', Journal of Material Culture.

Mukherjea, Bijan Kumar (1952) Hindu Law of Religious and Charitable Trusts, Calcutta: Eastern Law House. 
Ophir, Adi (2005) The Order of Evils: Toward an Ontology of Morals, New York: Zone Press.

Narayan, Ram (1875) 'Translation of the Ayodhya Mahatmya or 'Pilgrimage to Ayodhya", Journal of the Royal Asiatic Society of Bengal, Vol. XLIV: pp. 130-73.

New Catalogous Catalogorum: An Alphabetic Register of Sanskrit and Allied Works and Authors 1967, complied by V. Raghavan, T. Aufrecht, University of Madras.

Pandey, Panini; Pandey, Suryakaladevi (1975) Ayodhyamahatmya [Hindi, no publication information].

Pandey, Sriramagopala (1954) Sriramjanmabhumi ka Romanchkari Itihas [The Thrilling History of Sriramjanmabhumi], Ayodhya [no publication information].

Parikh, Sheetal (2005) 'Enshrining a Secular Idol: A Judicial Response to the Violent Aftermath of Ayodhya', Case Western Reserve Journal of International Law, 37(1): pp. 85-109.

Ricœur, Paul (1988) Time and Narrative Vol. 3, Chicago: The University of Chicago Press.

Searle, John (1958) ‘Proper Names’, Mind, 67(266), pp. 166-73.

Sharma, Ram Sharan (2001) 'The Ayodhya Issue’ in Robert Layton, Peter G. Stone \& Julian Thomas (eds.), Destruction and Conservation of Cultural Property, London \& New York: Routledge, pp. 127-38.

Sontheimer, Gunther (1964) ‘Religious Endowments in India: The Juristic Personality of Hindu Deities', Zeitschrift für vergleichende Rechtswissenschaft, 67(1), pp. 45-100.

\section{NOTES}

1. For Ayodhya as an urban settlement connected to the Rama legend, see the magisterial work of Bakker (1986) and Lutgendorf (1997: 19-54).

2. In colonial times the mosque was often referred to as the masjid-i-janmasthan (literally, mosque of the birthplace).

3. In civil jurisdiction, four basic suits deal with the Ayodhya dispute in Independent India. A Hindu resident of Ayodhya, who claimed his right to worship at the birthplace without hindrance, filed the first suit on January 16, 1950. The second suit (1959) was filed by the Nirmohi Akhara (cloister), claiming that it was the sole religious order charged with maintaining and managing the birthplace. The third suit (1961), filed by the Sunni Waqf Board, sought a decree that the religious structure was a mosque to be handed over to the Board. The Next Friends of the Deity on behalf of the child god Rama filed the fourth suit in 1989. It claimed that both the deity and the birthplace were juristic persons. This suit forms the backbone of the Allahabad High Court decision of 2010. I will discuss the judgment later in the paper.

4. The Government of India constituted the Liberhan Enquiry Commission on 16 December 1992 to enquire into the circumstances of the destruction of the mosque and to establish criminal culpability. After several delays the report was tabled in the Indian parliament in 2009.

5. Aijaz Ahmad (2000), Sara Ahmad (1996: 320-50) and Sheetal Parikh (2005: 85-109) argue that the destruction of the mosque posed a fundamental challenge to the secular republic. Parikh, for example, says that 'Ayodhya is not just a moment of India's history; it is inextricably linked to the nation's present and future' (p. 86). But this view of the secular does not consider that which challenges it-religious belief and worship. Jan-Peter Hartung, et al. (2003) consider the religious but evacuate it of its belief system. For the analysis of Ayodhya as cultural property see Ram Sharma (2001: 127-38).

6. I follow Ophir (2005: 44) to suggest that if law en-tongues the Babri Mosque, it does so by becoming complicit in the game of hide and seek. 
7. The NCC (New Catalogus Catalogorum, prepared by V. Raghavan), an alphabetic register of Sanskrit and allied works, mentions 36 recensions of the Ayodhya Mahatmya, derived in turn from the Skandapurana, the Padmapurana or from no works at all. We also find Hindi translations, such as those of Panini Pandey and Suryakaladevi Pandey, Sriramagopala Pandey or paraphrases, such as those of Ram Narayan (1875). I will base myself on this latter text since it was the guidebook used to map the city for the coronation of King Edward VII. For an authoritative description of the 3 major recensions of the AM, see Bakker (1986, Vol. I, Vol. II).

8. As I understand Kripke (1972), the basic idea of the rigid designator is one where the expression in question has a fixed designation (given the context of its use) when considering various counterfactual situations. Given this, the name Rama will not be able to designate in worlds where Rama does not exist. Rather than use Rama (or Ayodhya, or the Babri mosque) as a rigid designator, I assume that the meaning of a proper name is neither fixed nor determined, but is supported by a series of links. In so doing it may seem that my argument is derived from Searle's (1958) article on proper names. Names, he says, do not function as descriptions, but as 'hangars' around which descriptions congeal. Further, if names have sense it is only because they connect with objects to which they refer. For this reason, names can be substituted by definite descriptions. The material that I am working with shows that names are also descriptions, but descriptions activated by other names. Other names (I am thinking here of the name Babri Masjid) are by the same process de-activated (I thank Jacob Copeman for this insight). It seems to me more useful, therefore, to work with a family of names. This particular family, indicated by the union of Rama to Ayodhya, is as is true of most families, also haunted by an outsider or interloper-the Babri Masjid.

9. The story is obviously incomplete and may be filled in by other recensions. This incompleteness allows for additions, extrapolations and modifications, but it is not central to my purpose in the paper. Suffice it to say that this AM is a discourse in the sense that Benveniste (1971) outlines its distinction from historical narrative. Discourse, he says, designates 'every utterance assuming a speaker and a hearer, and in the speaker, the intention of influencing the other in some way' (Benveniste 1971: 209). Furthermore, distinct from narrative, discourse includes three basic tenses: the present, future and perfect tenses. The present is the basic tense of the discourse because it marks the contemporaneousness of what is stated with the instance of discourse. It is thus tied to the self-referential character of the instance of discourse. This instance, we will see later is a spectral present.

10. The city is the residence of the dynasty to which Rama belongs, the Iksvaku.

11. Rinamochan, the text says, is at a distance of 200 yards from Brahmakund. Its water joins the Saryu. A pilgrimage here is recommended for those in debt since it 'wipes off debts.' Likewise Papamochan, 40 yards from Rinamochan, erases sins. Its pilgrimage is recommended on the $5^{\text {th }}$ day of the light half of Sravana (July-Aug).

12. The Hindu calendar is made up of 12 months. Where relevant I have provided correlations with the Gregorian calendar. Each month of the Hindu calendar begins in the third week of the Gregorian month. Each Hindu month is also divided into a light and dark half, corresponding with the waxing and waning moon. The waxing phase is known as the Shukla, while the waning phase is called Krishna.

13. I have 27 affidavits of testifiers. While there is a standard form of description, I find that, unlike First Information Reports in the recording of a crime in the police station, these affidavits are marked by cross-referentiality. They anticipate arguments; provide a way of addressing the silences of other accounts and most often supporting the testimonies of others. This crossreferentiality creates the impression of the flow of time, making possible the process of remembering and commemorating the past. But from affidavits presented by Muslim defendants and plaintiffs, the mosque seems to be situated between the past and future horizon of Hindu forms of worship. 
14. Here I am in agreement with Kilroy-Marac (2014: 255-76). In the story she tells of ghostliness in a psychiatric clinic in Senegal, Kilroy-Marac moves between the actual and virtual to suggest that foreign ghosts haunt according to a different set of rules from domestic ghosts (2014: 264). Within the disputed complex in Ayodhya, it is as if the mosque is made foreign and thus a different set of rules must apply to its presence as an interloper or usurper.

15. In earlier papers I have argued that such bundles make up the idea of property (Mehta 2015), as much as they constitute the idea of the legal person (Mehta 2015, forthcoming).

16. An extensive literature discusses the deity as a jural person (Appadurai, 1981; Mukherjea, 1952; Sontheimer, 1964). I do not reference the intricate moves by which the jural deity changes its contours-from domestic disputes during the 1870s onwards, to its status in temples. In the story he tells of the Pathur Nataraja, Davis (2010: 195-206) shows how the Hindu god Siva became the owner of his own property, namely the Nataraja icon. Smuggled out of India in 1976, this icon reached the British museum for cleaning, where it was established that the Nataraja was a stolen art object. In the ensuing court case, Siva acted as plaintiff with the Indian government serving only as 'technical plaintiff.' Siva here was a juristic person and, as it turns out, a juristic agent, who could own property and seek its lawful return when expropriated. The distinction between person and property could not be sustained.

17. Situated in the precincts of the Mosque, the Ram Chabutra was an elevated platform. It marked the exact spot of the janmasthan.

18. The rules of evidence marshaled to support the view that the Rama deity and his birthplace were jural entities were again derived from eclectic sources-various translations of Valmiki's Ramayana, the Skandapurana, the 1875 Ayodhya Mahatmya, Edward Thornton's Gazetteer of 1858, Carnegie's report of 1870, the Imperial Gazetteer of 1905 and Neville's Fyzabad Gazetteer of 1905, the New Encyclopedia Britannica, Vol. IX and so on.

19. On the night of 21-22 December 1949, the deities of Ram Lala and his brothers, Lakshmana, Shatrughan and Bharata, were surreptitiously installed inside the central dome of the Babri Mosque. Following the installation, the mosque ceased to function as a site of Islamic prayers. Instead Hindus were allowed darshan from a distance. Effectively, the Babri Mosque lost its character as a place of worship from that date.

20. The Ram Chabutra, apparently marking the exact spot where Rama took birth, was an elevated platform located next to the actual mosque. It, too, was demolished in 1992.

\section{ABSTRACTS}

This paper studies the predicates associated with the name of the Hindu god Rama, as they come to inhabit the temple town of Ayodhya. My intention is to show how the name Rama is linked to the topography of Ayodhya, but also to a landscape that is marked by the absence of the Babri Mosque, demolished by members of the Hindu right in 1992. The name Rama imagines Ayodhya to be both a pastoral setting and a site of national regeneration. This is achieved by coupling the architectural spaces of Ayodhya to the many names of Rama, and to his kingdom. I suggest that the Rama deity, installed in the place of the mosque, acquires life in this combination. 
INDEX

Keywords: Rama, Ayodhya, Babri Masjid, haunting, legal personality of the deity

\section{AUTHOR}

DEEPAK MEHTA

Professor, Department of Sociology, Shiv Nadar University, Greater Noida, UP 